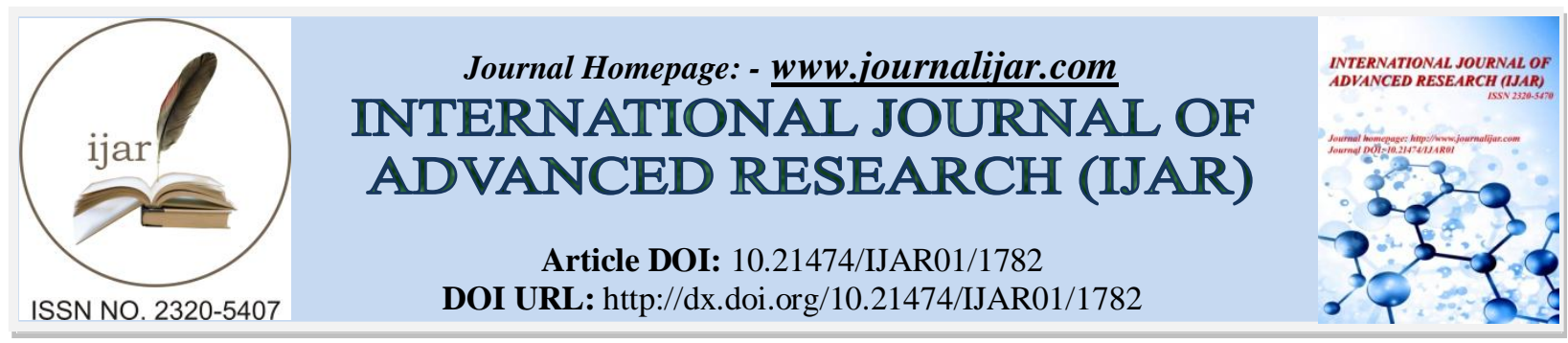

RESEARCH ARTICLE

\title{
HEALTH PROBLEMS OF SCHEDULED TRIBES IN KANYAKUMARI DISTRICT OF SOUTH TAMIL NADU.
}

Deepan.V and Ramachandran. $R$.

Assistant Professor, Department of Economics, Jairam Arts and Science College,Salem-08, Tamil Nadu.

\section{Manuscript Info}

Manuscript History

Received: 11 August 2016

Final Accepted: 22 September 2016

Published: October 2016

Key words:-

Tribal Health and Problems.

\section{Abstract}

In India, there are more than 400 tribal groups that constitute 8 percent of the nation's total population. Around 87 million persons have been enumerated in the country as members of Scheduled Tribes. They are socially and economically weaker and also under object poverty and live in a subsistence economy and general backwardness. This is because of their ill health which is a cause and consequence of poverty. The present study was undertaken Andipottai, Kazhaparai, Thanchanmalai, Thottamalai and Mudavarpottai settlements in Kanyakumari district. There is need for the educational empowerment of all tribal settlements in Kaniyakumari district. The Information Education and Communication (IEC) should reach all tribal for enhancement of knowledge of communicable and non communicable disease. The Behavioral Change Communication (BCC) should be strengthened to utilize more health care services.

Copy Right, IJAR, 2016,. All rights reserved.

\section{Setting:-}

Tribal groups are the earliest settlers of India. In India, there are more than 400 tribal groups that constitute eight percent of the nation's total population (Saha, 2003, Mitra and Singh, 2008). Around 87 million persons have been enumerated in the country as members of Scheduled Tribes (ST). The majorities of tribal people live in rural areas and are engaged in agricultural pursuit. Scheduled tribes also referred to as adivasis (original inhibitions' from Adi 'old' and vasi 'those who stay') are spread all over India with major concentrations across the central, northeast and western regions. The states, with tribal populations reported, within each group are as follows: the northeastern group consists of Mizoram (95 percent), Meghalaya (81 percent), Nagaland (73 percent), Arunachal Pradesh (62 percent), Manipur (26 percent) and Tripura (17 percent), the central group includes the states of Chhattisgarh (30 percent), Jharkhand (28 percent), Orissa (23 percent), Madhya Pradesh (21 percent) and Bihar ( 0.4 percent) and the remaining groups encompasses Rajasthan (14 percent), Gujarat (11 percent), Maharashtra (11 percent), Andhra Pradesh (7 percent), Karnataka (6 percent) and Goa (5 percent); any other states have a very small proportion of the tribal population (IIPS, 2006). Historically, tribal communities are spread both in the plains and hilly terrain in Tamil Nadu.

The adivasi in Kanyakumari district is named as Kani tribes. The Kanikars are generally known as Kanis. They are primitive tribe inhabitating the southernmost part of Tamil Nadu and Kerala state. Kar in Tamil denotes a measure of land (KaninilamVetam). The word kanikaran means a hereditary proprietor of land. They are known as kaniyans, velanmars, malairasan and malavedan (hunters of the forest). The word kanikars has been derived from the word kani,kani means privilege, the size of hundred pits of land, kani government (Tamil Lexicon, p316). Tribals are

Corresponding Author:- Deepan.V.

Address:- Assistant Professor, Department of Economics, Jairam Arts and Science College,Salem-08, 
traditional, conservative and unprivileged people. They are socially and economically weaker and also under object poverty and live in subsistence economy and general backwardness. This is because of their ill health which is a cause and consequence of poverty.

Tribal groups suffer from the nutritional deficiency diseases like endemic goiter, anemia. Other manifestations were pot belied school children, small body sizes, underweight adolescents and short life spans. Another set of nutritional problems develop from unsanitary food supplies and water contamination, less calories of food intake, which have much reflection on the health status of tribes. The tropical disease malaria is still rampant in the tribal areas of India. Low awareness among the clients is one of the major reasons of low utilization of services (Rajendran and Ramachandran, 2016). Lack of personal hygiene, poor sanitation, nutritional deficiency and poor mother and child health services, absence of health education, lack of national preventive programmes, and lack of available health services are responsibility for the poor health of the tribals. It is due to low income and other socio economic factors. Poverty and low health care expenditure always go together. As result, the health status of the tribal is in a precarious position. The present study focuses with fold objective to understand the health problems of Schedule Tribe in Kanyakumari District of South Tamil Nadu.

\section{Methods:-}

The present study was undertaken Andipottai, Kazhaparai, Thanchanmalai, Thottamalai and Mudavarpottai tribal settlements in Kanyakumari district. This study based on primary data and used simple random sampling technique. The study covers the socio-economic condition like income, expenditure, savings, age, marital status, health conditions and health problems of the respondents. From each settlement 30 samples were selected on the basis of convenience random at the total of 150 samples.

\section{Analysis and Discussion:-}

Sex distribution of the respondents is needed to know about the male and female ration of the respondents. As 46 percent of the sample respondents are male in all settlements and 54 percent of respondents are female in table-1. Age is the key variable in determine an individual's power, prestige, privilege and ranking in social life. Biologically are signifies the physical and mental maturity of an individual. Sociologically, are denotes the status of an individuals in group, be that his family, kinship or other larger and organized groups within the society. Around 20 percent of the respondents belong to below 30 years and 73 percent belongs to the age group of 31-60 years in all settlement. Only seven percent of the respondents belong to above 61 years in all settlements of Kanyakumari district. From sociological point of view, religion is one of the most powerful institutions, which regulate and guide the individual's actions as well as source of unity and solidarity of any group or community.

In all settlements, there were 93 percent of the respondents are Hindus and seven percent are Christians. Type of family is the basic unit of a social group and the parents and the children constitute a family. There are two types of family they are nuclear and joint family. It can be understood that seven percent of respondents are in the joint family and 93 percent in the nuclear family system.

Table 1:- Socio-economic Background of the Respondents

\begin{tabular}{|c|c|c|c|c|c|c|}
\hline Variable/settlements & Andipottai & Kazhaparai & Thanchanmalai & Thottamalai & MudavarPottai & Total \\
\hline \multicolumn{7}{|l|}{ Sex } \\
\hline Male & $11(8)$ & $9(6)$ & $17(11)$ & $15(10)$ & $17(11)$ & $70(46)$ \\
\hline Female & $19(12)$ & $21(14)$ & $13(9)$ & $15(10)$ & $13(9)$ & $80(54)$ \\
\hline \multicolumn{7}{|l|}{ Age } \\
\hline Below 30 & $5(3)$ & $8(5)$ & $7(5)$ & $5(3)$ & $5(4)$ & $30(20)$ \\
\hline $31-60$ & $22(14)$ & $19(14)$ & $23(15)$ & $23(15)$ & $23(15)$ & $110(73)$ \\
\hline Above 61 & $3(2)$ & $3(2)$ & - & $2(2)$ & $2(2)$ & $10(7)$ \\
\hline \multicolumn{7}{|l|}{ Religion } \\
\hline Hindu & $27(18)$ & $24(16)$ & $30(20)$ & $29(19)$ & $30(20)$ & $140(93)$ \\
\hline Christian & $3(2)$ & $6(4)$ & - & $1(1)$ & - & $10(7)$ \\
\hline \multicolumn{7}{|l|}{ Type of family } \\
\hline Joint family & $4(3)$ & $3(2)$ & $1(1)$ & - & $2(1)$ & $10(7)$ \\
\hline Nuclear family & $26(17)$ & $27(18)$ & $29(19)$ & $30(20)$ & $28(19)$ & $140(93)$ \\
\hline \multicolumn{7}{|l|}{ Size of family } \\
\hline Below 3 & $23(15)$ & $22(15)$ & $25(17)$ & $15(10)$ & $15(10)$ & $100(67)$ \\
\hline
\end{tabular}




\begin{tabular}{|c|c|c|c|c|c|c|}
\hline $4-5$ & $7(5)$ & $8(5)$ & $5(3)$ & $15(10)$ & $15(10)$ & $50(33)$ \\
\hline \multicolumn{7}{|l|}{ Education } \\
\hline Illiterate & $23(15)$ & $18(12)$ & $26(17)$ & $19(13)$ & $24(16)$ & $110(73)$ \\
\hline Primary & $3(2)$ & $6(3)$ & $1(1)$ & $5(3)$ & $4(3)$ & $19(12)$ \\
\hline Secondary & $2(1)$ & $4(3)$ & $1(1)$ & - & $2(1)$ & $9(6)$ \\
\hline Higher secondary & $2(1)$ & $1(1)$ & $1(1)$ & $4(3)$ & - & $8(6)$ \\
\hline Degree & - & $1(1)$ & $1(1)$ & $2(1)$ & - & $4(3)$ \\
\hline \multicolumn{7}{|l|}{ Occupation } \\
\hline Private & $2(1)$ & $4(3)$ & $6(4)$ & $4(3)$ & $2(1)$ & $18(12)$ \\
\hline Government & - & $1(1)$ & $2(1)$ & - & $3(2)$ & $6(4)$ \\
\hline Agriculture & $22(15)$ & $20(13)$ & $18(12)$ & $21(14)$ & $18(12)$ & $99(66)$ \\
\hline Business & $1(1)$ & $2(1)$ & $1(1)$ & $2(1)$ & $5(4)$ & $11(8)$ \\
\hline Self employed & $5(3)$ & $3(2)$ & $3(2)$ & $3(2)$ & $2(1)$ & $16(10)$ \\
\hline \multicolumn{7}{|l|}{ Annual Income } \\
\hline Less than 40000 & $30(20)$ & - & $30(20)$ & $30(20)$ & $30(20)$ & $120(80)$ \\
\hline Above 40001 & - & $30(20)$ & - & - & - & $30(20)$ \\
\hline
\end{tabular}

Source: Primary data

Note: Figure in the parenthesis is percentages

Around 67 percent of the respondents family size is below 3 and 33 percent of respondents are family size is 4 to 5 members. One of the indices ordinarily used for ascertaining the position of the group in the socio-economic context is the level of education. The status of the family depends to a certain degree on the educational level of its members. Education is the most powerful in enabling the social members to play their indispensable and vital role in the society. It is observed that 73 percent of the respondents are illiterate settlement, 12 percent have completed primary school education, six percent completed secondary school education, eight percent completed higher secondary education and four percent are completed graduate in all settlements of Kanyakumari district.

Occupation plays an important role to determine the status of the people. It shapes their job attitudes, aptitudes and enhances their job skills. Occupation is classified as professional business, agriculturalist and others. About 12 percent of the respondents have been employed in private organization, 66 percent agriculture, eight percent are in business, 10 percent are self employed and only four percent of the respondents in government job. Around 80 percent of the respondents belong in the income group of less than Rs.40000 and 20 percent belongs to the above Rs.40001 in all settlements of Kanyakumari district. The income of the tribal population is meager, not even substantial to meet the basic needs.

Health problems are influenced by various factors such as environment, food habit and other factors. At present every one of the family members is suffering from any one of the health problems. Especially the tribal population is staying far away from the main land of the Kanyakumari district. The common diseases are classified into twomajor diseases and minor diseases. The minor diseases are cough, fever, hearing impairment, joint paints, vomiting and major diseases refer to heart attack, diabetes, asthma, high blood pressure, nervous disorder and tuberculosis. The diseases wise classification of the sample respondents in presented in table-2.

Table 2:- Type of Disease.

\begin{tabular}{|l|c|c|c|c|c|l|}
\hline Particulars & Andipottai & Kazhaparai & Thanchamalai & Thottamalai & Mudavarpottai & Total \\
\hline Cough & $3(16)$ & $3(16)$ & $5(26)$ & $5(26)$ & $3(16)$ & $19(100)$ \\
\hline Fever & $3(13)$ & $5(18)$ & $4(18)$ & $3(13)$ & $7(31)$ & $22(100)$ \\
\hline Nervous disorder & $2(11)$ & $3(17)$ & $6(33)$ & $3(17)$ & $4(22)$ & $18(100)$ \\
\hline Hearing impairment & $3(18)$ & $2(12)$ & $4(23)$ & $5(29)$ & $3(18)$ & $17(100)$ \\
\hline Joint pain & $2(13)$ & $4(27)$ & $4(27)$ & $3(20)$ & $2(13)$ & $15(100)$ \\
\hline Heart complaints & $2(18)$ & $1(9)$ & $3(27)$ & $4(37)$ & $1(9)$ & $11(100)$ \\
\hline High Blood pressure & $3(36)$ & $1(13)$ & $2(25)$ & $1(13)$ & $1(13)$ & $8(100)$ \\
\hline Poor eye sight & - & - & - & $1(50)$ & $1(50)$ & $2(100)$ \\
\hline Diabetes & $4(25)$ & $3(19)$ & $2(12)$ & $3(19)$ & $4(25)$ & $16(100)$ \\
\hline Dysentery & $3(23)$ & $1(8)$ & $3(23)$ & $4(31)$ & $2(15)$ & $13(100)$ \\
\hline Asthma & $1(25)$ & $2(50)$ & $1(25)$ & - & - & $4(100)$ \\
\hline T.B & $2(22)$ & $1(11)$ & $2(22)$ & $3(34)$ & $1(11)$ & $9(100)$ \\
\hline
\end{tabular}

Source: Primary Data 
As 36 percent of the respondents are affected high blood pressure in Andipottai, 50 percent affected asthma in Kazhaparai, 33 percent affected nervous disorder in Thanchamalai, and 50 percent affected poor eye sight only in Thottamalai and Mudavarpottai. Overall 22 respondents affected fever, 19 affected cough, 18 affected nervous disorder in all settlement. There is a general agreement that the health status of the tribal population in India is very poor, deficient in sanitary conditions, personal hygiene and health education (Basu, 1994). All told, the whole tribal community is deficient in adequate food intake. The health problems of the tribal people of India depend upon the varied socio-economic, socio-culture and ecological settings.

The ability of the household to spend on health care facilities is an indicator of enlarging the capability of household's member. The Counselling for health related issues need immediate attention to health project and keep improve the human health and development for overall economic development (Rajendran and Ramachandran, 2015). The tribals in general suffer from skin diseases diarrahea, malaria, T.B., joint pain and other diseases related to malnutrition. Some of the diseases like jaundice and night blindness are successfully treated without complications. The people living in plain areas also depend on herbal medicines as they are very cost effectiveness and do not have side effects (Chakravarty, 2008).

\section{Conclusion:-}

The level of health is an indicator for their standard of living. In the study areas people have been suffered from various diseases such as 36 percent of the respondents are affected high blood pressure in Andipottai, 50 percent affected asthma in Kazhaparai, 33 percent affected nervous disorder in Thanchamalai, and 50 percent affected poor eye sight only in Thottamalai and Mudavarpottai. Overall 22 respondents affected fever, 19 affected cough, 18 affected nervous disorder in all settlement. There is need for hour to establish government clinic or motivate private doctors to establish hospital in these settlements and the government should more assistance to the private hospital. The medical personal should focuses on emphasizing the hygienic practices, because of there were 73 percent of the respondents illiteracy in the study areas.

\section{Suggestion:-}

To achieve holistic development, attention should be given more towards the health of the tribal in a realistic manner. Their health status can be improved significantly by scientifically executed intervention with target appropriate education material by picture formed and techniques. There is need for the educational empowerment of all tribal settlements in Kaniyakumari district. The Information Education and Communication (IEC) should reach all tribal for enhancement of knowledge of communicable and non communicable disease. The Behavioral Change Communication (BCC) should be strengthened to utilize more health care services.

\section{References:-}

1. Basu SK (1994), "The State of the Art: Tribal Health in India", in BasuSalil (Ed): Tribal Health in India, Delhi: Manak Publication Ltd., P.312.

2. Guite N and Acharya S (2006), "Indigenous medicinal Substances and Health Care, A Study AmongPaite Tribe of Manipur, India", Studies of Tribe and Tribal's, 4 (2):99-104.

3. International Institute for Population Sciences (IIPS) (2006), "National Health Family Survey-3",National Survey Report 2005-06, Mumbai.

4. Mitra A and Singh P (2008), "Trends in literacy Rates and Schooling among the Scheduled Tribe women in India", International Journal of Social Economics, 35 (1/2):99-110.

5. Saha P.K (2003), "The Status of Family Welfare Services in Tribal Areas: Highlights of the Evaluation Process",International Journal of Community Medicine, 28 (3).

6. Chakravarty B (2008), "Traditional and Modern Health Care Services in Tribal Areas",Kurukshetra, 6 (12), October.

7. Rajendran S and R.Ramachandran (2015), “Counselling for Patients in Rajapalayam Government Hospital", International Journal of Scientific Research, 4 (5):236-238.

8. Rajendran S and R.Ramachandran (2016), "Maternal and Child Health Care Services in Tamil Nadu",International Journal of Business and Administration Research Review, 1 (1):149-152. 